\title{
Peranan Institusi Hukum Islam Suprastruktur dan Infrastruktur dalam Penyelesaian Problematika Masyarakat
}

\author{
Yudi Arianto, Chamidah Alawiyah, Iqlima \\ Institut Agama Islam Nahdlatul Ulama Tuban \\ E-mail: Yudiarianto88@gmail.com,chamidahalawiyah@gmail.com, \\ Iimaiq53@gmail.com
}

\begin{abstract}
Abstrak: Institusi hukum Islam mempunyai peranan fital dalam menata dan mengarahkan umat, keberadaannya menjadi garda terdepan untuk memberikan kontrol terhadap problematika yang merebak di tengah masyarakat, oleh karenanya perbedaan yang terdapat ditengah masyarakat harus disikapi dengan bijak, dengan tidak menjadikannya sebagai alasan perpecahan dan kemelut sosial. Penelitian ini menggunakan metode penelitian kepustakaan. Hasil penelitian menunjukkan bahwa 1) Nilai-nilai keislaman sebenarnya telah tumbuh, jauh sebelum Indonesia merdeka, nilai-nilai tersebut kemudian bersinergi dengan aspek kebudayaan dan aspek sosial dalam masyarakat. 2) prinsipprinsip keislaman yang telah membaur dengan kebudayaan yang ada selanjutnya mampu bertransisi ke dalam pranatapranata sosial dalam masyarakat, 3) untuk mempertegas kedudukan lembaga infrastruktur dalam masyarakat sehingga mempunyai kekuatan hukum mengikat untuk warga Negara, maka pemerintah dengan asas kedaulatannya membentuk lembaga Islam yang mempunyai kekuatan hukum mengikat kepada warga Negara Indonesia yang Muslim, wujud keberadaan lembaga suprastruktur. 4) Baik lembaga infrastruktur maupun suprastruktur keduanya mempunyai andil besar dalam memajukan potensi warga Negara terutama yang beragama Islam, keberadaan lembaga tersebut mampu memberikakan kontrol sikap masyarakat yang jauh dari nilai religiuisitas.

Kata kunci: Institusi hukum, infrastruktur, problematika masyarakat.
\end{abstract}

\section{Pendahuluan}

Kebutuhan masyarakat Islam di Indonesia terhadap pranata sosial atau lembaga Islam sudah mendesak untuk saat ini, Indonesia yang mayoritas penduduknya beragama Islam seringkali dihadapkan pada berbagai problematika yang akut menyangkut keyakinan beragama, dalam beberapa tahun terakhir terdapat banyak aliran keagamaan yang 
dianggap sesat oleh masyarakat, tentu saja dari sekian banyak aliran tersebut berpotensi besar menimbulkan keresahan di tengah pergumulan masyarakat muslim, keresahan tersebut seringkali berimbas kepada tindakan main hakim sendiri, dan tidak mengindahkan nilai-nilai etika dan estetika dalam beragama, yang selalu menjujung tinggi sikap toleran dalam bentuk musyawarah secara kooperatif.

Pada tahun 2001 misalnya kita kenal Lia Eden yang dengan bangganya menjustifikasi dirinya sebagai penyambung kalam Tuhan, ia mengajak orang-orang disekitarnya untuk mengikuti paham keagamaan yang diyakini akan mendatangkan keselamatan hidup, dialah perempuan kontroversial, pemimpin agama sesat kaum eden. Dalam syi'arnya, perempuan kelahiran Surabaya, 21 Agustus 1947, itu mengaku sebagai Jibril dan Mesias yang muncul di dunia sebelum kiamat. Dia juga mengaku sebagai reinkarnasi bunda Maria, Ibu dari Yesus Kristus. Sedangkan anaknya, Ahmad Mukti mengklaim reinkarnasi Isa Almasih.

Dalam beberapa tahun kebelakang dikenal pula jamaah al-Qiyadah al-Islamiyah yang dimotori oleh Ahmad Mushaddeq, Ahmad mushaddeq mengaku sebagai nabi pengganti Nabi Muhammad, Wahyu yang diterima Moshaddeq bukan berupa kitab tapi pemahaman yang benar dan aplikatif mengenai ayat-ayat Al-Quran yang menurut pendapat Mushaddeq telah disimpangkan sepanjang sejarah, dalam beberapa kesempatan dia juga tidak mewajibkan shalat, puasa, zakat dan haji sebagaimana yang diamalkan umat Islam, selain al-qiyadah terdapat pula beberapa nama jamaah yang diklaim sesat di Indonesia. Dan merupakan wujud penyimpangan terhadap ajaran agama Islam, di antaranya: Komunitas Penimbrung Qur'an Sunnah, NII (Negara Islam Indonesia) asalnya DI (Darul Islam, diproklamasikan Sekarmadji Maridjan Kartosoewirjo, 7 Agustus 1949 di Cisayong Tasikmalaya Jawa Barat), Inkar Sunnah (Orang yang tidak mempercayai hadits Nabi saw sebagai landasan Islam, maka dia sesat), Salamullah, Isa Bugis, Lembaga Kerasulan dan banyak lagi yang lainnya.

Keberadaan aliran tersebut tentu tidak hanya berimplikasi pada potensi penistaan agama akan tetapi dapat menimbulkan keresahan di tengah masyarakat, di sinilah salah satu fungsi dari lembaga Islam yang ada yaitu sebagai lembaga yang dapat menampung aspirasi masyarakat Islam, lembaga Islam akan memberikan klarifikasi kepada aliran atau paham yang telah keluar dari prinsip agama Islam, seperti halnya pranata 
Sosial MUI (Majlis Ulama' Indonesia) lembaga ini melahirkan fatwa-fatwa dibidang keagamaan yang terkait erat dengan kondisi masyarakat.

Selanjutnya menilik bagaimana yang disebut sebagai lembaga itu sendiri yaitu sebagaimana ungkapan Satjipto Raharjo bahwa institusi pada hakikatnya merupakan alat perlengkapan masyarakat untuk menjamin agar kebutuhan-kebutuhan dalam masyarakat dapat dipenuhi secara seksama, keseksamaan di sisni pada pokoknya mengandung makna keteratuan. ${ }^{1}$ Jadi yang dimaksud Institusi Hukum Islam di sini adalah Sistem norma yang didasarkan pada ajaran Islam, yang sengaja diadakan untuk memenuhi kebutuhan umat Islam yang sangat beragam mengikuti perkembangan zaman, kebutuhan tersebut di antaranya adalah kebutuhan keluarga, kebutuhan pendidikan, kebutuhan hukum, kebutuhan ekonomi, politik, saosial dan budaya.

\section{Institusi Hukum Islam yang di Bentuk Melalui Suprastruktur}

Pengembangan hukum Islam melalui berbagai saluran baik melalui pranata sosial yang tersedia maupun badan penyelenggara kekuasaan Negara: legislatif, berupa Undang-undang 2 .

Adapun perundang-undangan yang lahir sebagai sikap kritis dari badan legislatif terhadap kepentingan umat Islam di Indonesia di antaranya adalah, dasar hukum yang menjamin kebebasan beragama di Indonesia terdapat pada pasal 28E ayat (1) UUD 1945, pasal 28E ayat (2) UUD 1945 juga menyatakan bahwa setiap orang berhak atas kebebasan meyakini kepercayaan. Selain itu dalam pasal 281 ayat (1) UUD 1945 juga diakui bahwa hak untuk beragama merupakan hak asasi manusia. Undang-Undang RI No.7 tahun 1989 tentang Peradilan Agama, UndangUndang RI No.3 Tahun 2006 tentang perubahan atas UU No.7 Tahun 1989 tentang Peradilan Agama, UU RI No.50 Tahun 2009 tentang perubahan kedua atas UU No.7 Tahun 1989 Tentang peradilan Agama. UndangUndang RI No.1 Tahun 1974 tentang perkawinan, Undang-undang No. 23 Tahun 2011 sebagai perubahan Undang-Undang RI No.38 Tahun 1999 tentang pengelolaan zakat. UU No. 17 Tahun 1999 tentang penyelenggaraan haji. Undang-undang RI No. 41 Tahun 2004 Tentang wakaf, Undang-undang RI No. 19 Tahun 2008 tentang surat berharga syari'ah Negara, Undang-undang RI No. 21 Tahun 2008 tentang

\footnotetext{
1 Satjipto Rahardjo, Ilmu Hukum, (Bandung: PT. Citra Aditya Bakti, 2000), hlm, 118.

${ }^{2}$ Cik Hasan Bisri, Hukum Islam Dalam tatanan Masyarakat Indonesia, Cet. Pertama, (Jakarta: Logos, 1998), hlm, 113.
} 
perbankan syari'ah, Lahirnya UU No. 18 Tahun 2001 tentang Nangroe Aceh Darussalam yang member otonomi Khusus kepada Daerah Istimewa Aceh untuk menerapkan syari'at Islam, hal ini menunjukkan bahwa ajaran Islam telah terimplementasi dalam kehidupan sehari-hari masyarakat Islam. Lahirnya UU No. 21 Tahun 2008 tentang perbankan syari'ah, Lahirnya PERMA No. 02 tahun 2008 pada tanggal 10 september 2008 tentang kompilasi hokum Ekonomi Syari'ah, meskipun saat ini kedudukannya hanya sebagai kitab pedoman, namun ke depan dapat diperjuangkan melalui jalur legislasi sebagai kitab Undang-Undang. ${ }^{3}$

Eksekutif yaitu peraturan Pemerintah, instruksi Presiden, peraturan menteri Agama, peraturan menteri dalam negeri, dan keputusan menteri Agama. serta yudikatif, yaitu putusan Pengadilan Agama dan pengadilan negeri. ${ }^{4}$ Adapun Institusi hukum Islam yang dibentuk oleh pemerintah atau badan penyelenggara kekuasaan Negara (Suprastruktur) terbagi menjadi dua: pertama, di bidang peradilan/kehakiman (Yudikatif), kedua, di bidang pemerintah/menteri Agama (Eksekutif).

\section{Institusi Hukum Islam Bidang Pemerintah (Eksekutif)}

Dalam masa pra-demokrasi terpimpin, yaitu November 1945 sampai juni 1959, kita kenal badan eksekutif yang terdiri atas presiden dan wakil presiden, sebagai bagian dari badan eksekutif yang tak dapat diganggu gugat, dan menteri-menteri yang dipimpin oleh seorang perdana menteri dan yang bekerja atas dasar tanggung jawab menteri. Kabinet merupakan kabinet yang dipimpin oleh wakil presiden Moh.Hatta, yang karena itu dinamakan kabinet presidensial. Mulai juni 1959 undang-undang dasar berlaku kembali dan menurut ketentuan undang-undang dasar itu badan eksekutif terdiri atas seorang presiden, wakil presiden, beserta menteri-menteri. Menterimenteri membantu presiden dan diangkat serta diberhentikan olehnya. ${ }^{5}$

Adapun yang erat kaitannya dengan persoalan institusi keIslaman maupun keluarga Islam adalah Departemen Agama, Kementerian Agama adalah instansi pemerintah yang bertugas melaksanakan tugas

\footnotetext{
${ }^{3}$ Cik Hasan Bisri, Hukum Islam Dalam tatanan Masyarakat Indonesia, Cet. Pertama, (Jakarta: Logos, 1998), hlm, 114.

${ }^{4}$ Miriam Budiardjo, Dasar-Dasar Ilmu politik, (Jakarta: PT. Gramedia Pustaka Utama, 2008), hlm,310.

5 Miriam Budiardjo, Dasar-Dasar Ilmu politik, (Jakarta: PT. Gramedia Pustaka Utama, 2008), hlm,310.
} 
umum pemerintah disektor keagamaan. Pembangunan bidang agama sesuai dengan kebijakan pembangunan nasional adalah untuk menciptakan manusia berakhlaq berbudipekerti luhur, beriman dan bertaqwa kepada Tuhan Yang Esa, selain itu kehadiran Kementerian Agama adalah memberikan jaminan hukum dan pelayanan kehidupan beragama, bagi segenap bangsa Indonesia, sesuai dengan amanah Pancasila dan Undang Undang Dasar 1945.

Tugas pemerintah dalam hal ini Kementerian Agama adalah menfasilitasi kepentingan masyarakat beragama tersebut sesuai dengan tupoksi badan pemerintah lainnya. Karena pembangunan masyarakat beragama adalah pembangunan masyarakat itu sendiri, maka hampir semua departemen mempunyai keterlibatan dalam pembangunan masyarakat beragama tersebut, sesuai dengan tupoksinya apalagi Departemen Dalam negeri melalaui program dinas istansinya, baik Diknas, Pertanian, Perkebunan, Perindustrian Perdagangan, Kesehatan dan lain sebagainya.

Kementrian agama dalam menjalankan tugasnya, melakukan beberapa fungsi sebagai berikut;

a. Perumusan, penetapan dan pelaksanaan kebijakan dibidang bimbingan masyarakat Islam, Kristen, Katolik, Hindu, Budha, dan Konghucu, penyelenggaraan haji dan umrah dan pendidikan agama dan keagamaan;

b. Koordinasi pelaksanaan tugas, pembinaan, pemberian dukungan administrasi kepada seluruh organisasi di lingkungan Kementrian Agama;

c. Pengelolaan barang milik/kekayan negara yang menjadi tanggung jawab Kementrian Agama;

d. Pengawasan dan pelaksanaan tugas di lingkungan Kementrian Agama;

e. Pelaksnaaan bimbingan teknis dan supervises atas pelaksanaan urusan Kementrian Agama di daerah;

f. Pelkasanaan kegiatan teknis dari pusat sampai ke daerah;

g. Pelaksanaan pendidikan, pelatihan, penelitian, dan pengembangan di biang agama dan keagamaan;

h. Pelaksanaan penyeenggaraan jaminan produk halal; 
i. Pelaksanaan dan dukungan substantive kepada seluruh organisasi di lingkungan Kementrian Agama. ${ }^{6}$

\section{Bidang Peradilan/Kehakiman (Yudikatif)}

Dalam doktrin trias politika, baik yang diartikan sebagai pemisahan kekuasaan maupun pembagian kekuasaan, khusus untuk pembagian kekuasaan yudikatif, prinsip yang tetap dipegang adalah bahwa dalam tiap Negara hukum badan yudikatif haruslah bebas dari campur tangan badan eksekutif, ini dimaksudkan agar badan yudikatif dapat berfungsi secara sewajarnya demi penegakan hukum dan keadilan serta menjamin hak-hak asasi manusia. ${ }^{7}$

Pada konteks Indonesia, pada periode sejarah penegakkan hukum yang memperlihatkan bahwa kekuasaan kehakiman belum dapat dikualifikasi sebagai independen. Indikasi atas hal itu dapat dikemukakan dari berbagai hal sebagai berikut, yaitu:

a. Di era kolonialisme, hakim pada hoogerechtsthof dan Raad van Justitie adalah pegawai yang terpisah dari pemerintahan, sedangkan ketua Landraad di Jawa dan Madura dan di sebagian luar Jawa dan Madura adalah pegawai pemerintahan yang biasanya berada di bawah Departemen Kehakiman.

b. Pada zaman Orde Lama, kekuasaan kehakiman ditempatkan sebagai alat revolusi hukum untuk memenuhi rasa keadilan masyarakat, Pasal 19 Undang Undang No. 19 Tahun 1964 menyatakan "Demi kepentingan revolusi, kehormatan Negara dan Bangsa atau kepentingan masyarakat yang sangat mendesak, Presiden dapat turut atau campur-tangan dalam soal-soal pengadilan". Begitupun halnya dengan otoritas dari lembaga penegakan hukum lainnya. ${ }^{8}$

c. Pada era Orde Lama ini, Presiden menempatkan Ketua Mahkamah Agung sebagai Menteri Kabinet dengan 3 (tiga) jabatan, yaitu: Menteri Penasihat Hukum Presiden, Menteri

\footnotetext{
6 Tugas dan Fungsi Kementrian Agama RI, https://kemenag.go.id/artikel/tugas-danfungsi, Akses 19 April 2020.

7 Miriam Budiardjo, Dasar-Dasar Ilmu politik, (Jakarta: PT. Gramedia Pustaka Utama, 2008), hlm 356.

8 Pasal 14 ayat (2) Undang Undang No. 19 Tahun 1964 tentang Ketentuan-Ketentuan Pokok Kekuasaan kehakiman menyatakan "Untuk menegakkan hukum sebagai alat revolusi dan/atau untuk memenuhi rasa keadilan masyarakat, Penuntut Umum berhak meminta mengenai perkaraperkara kejahatan tertentu yang ditetapkan di dalam Undang-undang".
} 
Kehakiman dan Menteri yang menjabat dan merangkap juga sebagai Ketua Mahkamah Agung. ${ }^{9}$

d. Pada Orde Baru, Presiden tidak lagi menempatkan Ketua Mahkamah Agung dibawah kekuasaan Presiden tetapi syaratsyarat seorang hakim untuk dapat diangkat dan diberhentikan diatur di dalam Undang Undang dan di dalam perundangan dimaksud ada kewenangan Presiden untuk menentukan hakim dimaksud. ${ }^{10}$

Uraian seperti tersebut di atas menjelaskan dan memperlihatkan bahwa kekuasaan atau kepentingan eksekutif mempunyai intensi untuk melakukan intervensi pada kepentingan kekuasaan kehakiman. Intervensi dimaksud menyebabkan kekuasaan kehakiman tidak sepenuhnya independen dihadapan kekuasaan. Pada kondisi sedemkian maka tidaklah dapat diharapkan, kekuasaan kehakiman dapat menjalankan kekuasaannya secara merdeka untuk menegakkan hukum dan keadilan.

Tetapi kemudian, Undang Undang Dasar pasca amandemen lebih tegas mengatur kekuasaan kehakiman dengan menyatakan "kekuasaan kehakiman merupakan kekuasaan yang merdeka untuk menyelenggarakan peradilan guna menegakkan hukum dan keadilan". Konstitusi dimaksud juga merumuskan secara tegas, siapa saja lembaga yang menjadi penyelenggara dan bagian dari kekuasaan kehakiman, merumuskan tugas dan wewenangnya serta hal lain yang berkaitan dengan pengangkatan dan syarat menjadi Hakim Konstitusi dan anggota Komisi Yudisial. ${ }^{11}$

Karna fokus pembahasan penelitian ini tentang Institusi hukum Islam maka yang penulis maksudkan di sini adalah lembaga peradilan agama. Peradilan agama merupakan proses pemberian keadilan

\footnotetext{
9 Philippus M Hadjon, Lembaga Tertinggi dan Lembaga -lembaga Tinggi Negara sesuai Undang Undang Dasar 1945: Suatu Analisa Hukum dan Kenegaraan,(Surabaya: PT Bina Ilmu, 1992), halaman 69.

10 Pasal 8 ayat (1), ayat (2) dan ayat (3) Undang Undang No. 14 tahun 1985 tentang Mahkamah Agung menyatakan sebagai berikut: (1) Hakim Agung diangkat oleh Presiden selaku Kepala Negara dari daftar nama calon yang diusulkan oleh Dewan Perwakilan Rakyat; (2) Daftar nama calon sebagaimana dimaksudkan dalam ayat (1) diajukan oleh Dewan Perwakilan Rakyat kepada Presiden selaku Kepala Negara setelah Dewan Perwakilan Rakyat mendengar pendapat Mahkamah Agung dan Pemerintah; dan (3) Ketua dan Wakil Ketua Mahkamah Agung diangkat oleh Presiden selaku Kepala Negara di antara Hakim Agung yang diusulkan oleh Dewan Perwakilan rakyat

${ }^{11}$ Lihat Pasal 24, Pasal 24A, Pasal 24B dan Pasal 24C Undang Undang Dasar 1945
} 
berdasarkan hukum Islam kepada orang-orang Islam yang dilakukan dipengadilan agama dan pengadilan tinggi agama, keberadaan peradilan agama dalam sistem peradilan nasional Indonesia, merupakan salah satu pelaksana kekuasaan kehakiman di Indonesia. ${ }^{12}$

Peradilan agama telah tumbuh dan melembaga di bumi nusantara sejak agama Islam dianut oleh penduduk yang berada di wilayah ini, berabad-abad sebelum kedatangan penjajah, keberadaan peradilan agama pada waktu itu belum mempunyai landasan hukum secara formal. Peradilan Agama ini muncul bersamaan dengan adanya kebutuan dan kesadaran hukum umat Islam Indonesia. ${ }^{13}$

Pengakuan akan adanya peradilan agama sangatlah berarti dalam negeri ini meskipun dalam prakteknya pelaksanaan lembaga peradilan ini selalu disetir dan diintervensi oleh pihak kolonial, oleh karena itu, keberadaan peradilan agama seperti itu belum menjamin terlaksananya lembaga peradilan yang didasarkan pada nilai-nilai keIslaman. Berbagai usaha telah dilakukan umat Islam dalam rangka mewujudkan lembaga peradilan Agama yang diimpikan. Usaha ini ternyata memakan waktu yang cukup lama. Setelah melalui berbagai tahapan, baru pada tahun 1989 pemerintah Indonesia mengeluarkan undang-undang no.7 tahun 1989 yang khusus mengatur Peradilan Agama, dengan keluarnya undang-undang ini maka keberadaan Peradilan Agama mempunyai landasan hukum yang formal dan diakui sejajar dengan badan-badan peradilan lainnya yang sama-sama melaksanakan fungsi kehakiman di Indonesia.

\section{Institusi Hukum Islam yang di Bentuk Melalui Infrastruktur}

Institusi hukum Islam yang dibentuk melalui pranata sosial yang tersedia (infrastruktur), yaitu melalui organisasi sosial maupun kemasyarakatan, ${ }^{14}$ baik yang bergerak di bidang pendidikan lalu diasosiasikan dalam bentuk pesantren dan madrasah, maupun dalam bidang lainnya, seperti fatwa yang diapresiasikan melalui MUI, institusi eonomi yang diasosiasikan menjadi Baitul Mal Wa Tamwil (BMT),

\footnotetext{
12 Mohammad Daud Ali, Hukum Islam: Pengantar Ilmu Hukum dan Tata Hukum Islam di Indonesia, cetakan ke-V (Jakarta:PT. Raja Grafindo Persada, 1996), hlm, 251.

13 Munawir Sjadzali, Landasan pemukiran politik hukum Islam dalam rangka menentukan peradilan Agama di Indonesia, dalam Djun Surdjaman (ed), Hukum Islam di Indonesia:Pemikiran dan praktek, (Bandung: Remaja Rosdakarya, 1991), hlm, 42.

14 Cik Hasan Bisri, Hukum Islam Dalam tatanan Masyarakat Indonesia, Cet. Pertama, (Jakarta: Logos, 1998), hlm, 113.
} 
institusi zakat yang diasosiasikan menjadi Badan Amil Zakat, Infaq dan Shadaqah (BAZIS), institusi dakwah yang diasosiaikan menjadi Lembaga Dakwah Kampus (LDK). Semua institusi yang ada di Indonesia itu bertujuan memenuhu kebutuhan masyarakat Muslim, baik kebutuhan fisik maupun kebutuhan nonfisik, institusi tersebut di antaranya ialah:

\section{Nahdlatul Ulama}

Nahdlatul Ulama (NU) merupakan organisasi keagamaan terbesar di Indonesia yang didirikan pada tanggal 16 Rajab $1344 \mathrm{H}$ (31 Januari 1926 M) di Surabaya oleh beberapa ulama terkemuka yang kebanyakan adalah pemimpin/pengasuh pesantren dan pelopor utamanya adalah KH. Hasyim Asyari, pendiri sekaligus pengasuh Pon Pes. Tebuireng-Jombang pada tahun itu. Tujuan didirikannya adalah berlakunya ajaran Islam Ahlussunnah Wal Jama'ah (Aswaja) dan menganut salah satu mazhab empat. Ini berarti NU adalah organisasi keagamaan yang secara konstitusional membela dan mempertahankan Aswaja, dengan disertai batasan yang fleksibel. ${ }^{15}$

Sebagai organisasi sosial keagamaan (Jam'iyah Diniyah wal Ijtima'iyah), NU merupakan bagian integral dari wacana pemikiran sunni. Terlebih lagi, jika kita telusuri lebih jauh, bahwa penggagas berdirinya NU memiliki pertautan sangat erat dengan para ulama "Haramain" (Makkah-Madinah) pada masa di bawah kekuasaan Turki Usmani yang ketika itu berhaluan Aswaja.

Selama ini image masyarakat terhadap NU terlanjur miring dengan jargon sebagai kaum tradisionalis, kolot, irasional dan jumud (stagnan) dalam pemikiran. Tentu saja image tersebut tidak berdasar. Jika NU statis, bagaimana mungkin memiliki umat 35 juta yang tersebar di seluruh tanah air dan memiliki kredo (kaidah hukum) AlMukhafatdlatu 'Ala Qadimish Shalih Wal Ahdu Bil Jadidil Ashlah (mempertahankan nilai dan tradisi lama yang dianggap baik dan relevan, dan akomodatif terhadap nilai dan tradisi baru yang lebih baik). ${ }^{16}$

\footnotetext{
15 Th. Sumartana, dkk, Pluaralisme,konflik dan Pendidikan Agama di Indonesia, (Yokyakarta:Dian Interfiedi 2001), 81-83.

${ }^{16}$ Ben Anderson (pakar studi tentang Indonesia dari Amerika) mengeluhkan sedikitnya perhatian ilmiah yang diberikan pada NU. Padahal NU yang dianggap sebagai simbol Islam tradisionalis, menurutnya, memainkan peran signifikan dalam berbagai perubahan sosial dan politik di Indonesia. U. Tanthowi, Pramono, Muhammadiyah dan NU dalam Kompetisi Makna Civil Society. (Jakarta : Artikel Kompas, 6 Juli 2001).
} 
Keadaan agak tertolong, setelah NU secara yuridis menjustifikasikan satu keputusan monumental bagi reformasi secara kritis dan analitis dalam institusi tertinggi dibawah Muktamar yaitu Musyawarah Nasional Alim Ulama di Bandar Lampung pada tahun 1992. ${ }^{17}$ Dalam keputusan tersebut disepakati bahwa sistem pengambilan keputusan hukum dalam Bahtsul Masa'il Diniyah (pembahasan masalah-masalah agama) bisa dilaksanakan dengan pola bermazhab secara qauli (tekstual) maupun manhaji (kontekstual). Hal ini memberikan kemungkinan untuk mengikuti manhaj, jalan pikiran dan kaidah hukum yang telah disusun oleh para Imam mazhab. Begitupun dalam bidang akidah, tidak mustahil terjadi pembaharuan pemikiran sepanjang sejalan dengan manhaj Imam Abu Hasan Al-Asy'ari dan Imam Abu Mansur Al-Maturidi. Pola berpikir semacam ini dapat diketahui pada pemikiran Al-Baqillani, AlBaghdadi, Al-Juwaini, Al-Ghazali, Al-Syahrastani dan Al-Razi.

\section{Muhammadiyah}

Muhammadiyah yang didirikan oleh KHA.Dahlan di Yogyakarta (1912), dalam perjalanan sejarahnya selama lebih dari 85 tahun telah menunjukkan kemampuannya menghadapi berbagai perubahan sosial tanpa kehilangan identitasnya sebagai gerakan Islam amarmakruf nahi-munkar. Setidak-tidaknya ada lima era perubahan sosial dan proses pembangunan bangsa yang telah dilalui oleh Muhammadiyah dengan relatif mulus. ${ }^{18}$

Muhammadiyah sejak kelahirannya dikenal sebagai gerakan pembaharu Islam dengan jargon-jargon ijtihad dan tajdidnya yang direalisasikan dalam bidang-bidang sosio-kultural dengan amal usaha di bidang pendidikan, sosial-kemasyarakatan dan kegiatan keagamaan. Karena sepanjang sejarahnya Muhammadiyah lebih menonjol gerakannya di bidang amal usaha sosial dibandingkan dengan produk pemikiran keagamaannya, maka Muhammadiyah

\footnotetext{
17 Moh Ali Aziz, "Hubungan Antar Umat Beragama Dalam Perspektif Ajaran Islam", Dialog Mahasiswa Intern Dan Antar Umat Beragama Se Jawa Timur, (Surabaya, 2001), 6.

${ }^{18}$ Era perjuangan melawan kolonialisme, era kemerdekaan, era transisi dari Orde Lama ke Orde Baru, era pembangunan bangsa dengan pengukuhan Pancasila sebagai asas tunggal berbangsa dan bernegara, dan ke lima masa peralihan dari Orde Baru ke era reformasi. Faisal Ismail, Islam Tranformasi Sosial dan Kontinuitas Sejarah (Yogyakarta: Tiara Wacana, 2001), 185-186.
} 
lebih dikenal sebagai gerakan amal (praksis) bukan sebagai gerakan pemikiran.

Walaupun demikian karena apa yang telah dilakukan Muhammadiyah dengan dampak sosialnya yang begitu besar itu merupakan implementasi dari hasil ijtihadnya, maka dapat diasumsikan bahwa ada mekanisme kerja pembaharuan pemikiran keagamaan yang dilaksanakan Muhammadiyah dalam menjalankan misinya sehingga ia disebut gerakan pembaharuan dalam Islam. ${ }^{19}$

\section{Majelis Ulama Indonesia}

Majelis Ulama Indonesia adalah wadah atau majelis yang menghimpun para ulama, zuama dan cendekiawan muslim Indonesia untuk menyatukan gerak dan langkah-langkah umat Islam Indonesia dalam mewujudkan cita-cita bersama. Majelis Ulama Indonesia berdiri pada tanggal, 7 Rajab $1395 \mathrm{H}$, bertepatan dengan tanggal 26 Juli 1975 di Jakarta, sebagai hasil dari pertemuan atau musyawarah para ulama, cendekiawan dan zu'ama yang datang dari berbagai penjuru tanah air. MUI berdiri bertepatan ketika bangsa Indonesia tengah berada pada fase kebangkitan kembali, setelah 30 tahun merdeka, di mana energi bangsa telah banyak terserap dalam perjuangan politik kelompok dan kurang peduli terhadap masalah kesejahteraan rohani umat. Selama dua puluh lima tahun berdiri, Majelis Ulama Indonesia sebagai wadah musyawarah para ulama, zu'ama dan cendekiawan muslim. Dan masih terdapat banyak organisasi kemasyarakatan lainnya.seperti, Persatuan Islam (Persis), Hidayatulloh, Front Pembela Islam dan lain sebagainya.

\section{Peran dan Fungsi Institusi Hukum Islam Suprastruktur}

1. Peradilan Agama

Pengadilan Agama bertugas dan berwenang mengadili perkara yang menjadi kewenangan Pengadilan Agama dalam tingkat Pertama. Sebagaimana telah diatur dalam Undang-Undang Nomor 7 Tahun 1989 jo. Undang-Undang Nomor 3 tahun 2006, tentang Perubahan atas Undang-Undang Nomor 7 tahun 1989 tentang Peradilan Agama yakni menyangkut perkara-perkara: Perkawinan, Waris, Wasiat, Hibah, Wakaf, Zakat, Infaq, Shadaqah dan Ekonomi Syari'ah.

${ }^{19}$ Fatkhurrahman Djamil, Metode Ijtihad Majlis Tarjih Muhammadiyah, (Jakarta: Logos, 1995), hlm.10 
Selain kewenangan tersebut, pasal 52A Undang-Undang Nomor 3 tahun 2006 menyebutkan bahwa "Pengadilan agama memberikan istbat kesaksian rukyat hilal dalam penentuan awal bulan pada tahun Hijriyah". Penjelasan lengkap pasal 52A ini berbunyi: "Selama ini pengadilan agama diminta oleh Menteri Agama untuk memberikan penetapan (itsbat) terhadap kesaksian orang yang telah melihat atau menyaksikan hilal bulan pada setiap memasuki bulan Ramadhan dan awal bulan Syawal tahun Hijriyah dalam rangka Menteri Agama mengeluarkan penetapan secara nasional untuk penetapan 1 (satu) Ramadhan dan 1 (satu) Syawal. Pengadilan Agama dapat memberikan keterangan atau nasihat mengenai perbedaan penentuan arah kiblat dan penentuan waktu shalat. Di samping itu, dalam penjelasan UU nomor 3 tahun 2006 diberikan pula kewenangan kepada PA untuk Pengangkatan Anak menurut ketentuan hukum Islam.

2. Kementerian Agama RI

Tugas pokok kementerian Agama ada 5 program pokok, yaitu (1)

Meningkatkan pemahaman dan pengamalan agama,

Meningkatkan Kerukunan Umat Beragama, (3) Meningkatkan mutu pendidikan agama (4) Meningkatkan mutu pelayanan haji (5) Meningkatkan tata kelola pemerintahan yang baik.

Peran dan Fungsi Institusi Hukum Islam Infrastruktur

Organisasi Islam mempunyai peranan fital dalam menata dan mengarahkan umat, keberadaan organisasi ini menjadi garda terdepan untuk memberikan kontrol terhadap problematika yang merebak di tengah masyarakat, oleh karenanya perbedaan yang terdapat antara satu ormas dengan ormas lainnya harus disikapi dengan bijak, dengan tidak menjadikannya sebagai alasan perpecahan dan kemelut sosial. Perbedaan tersebut harus diarahkan kearah perbaikan, serta menjadikannya layaknya pelangi dengan warna-warna yang berbeda namun justru lebih tampak menarik karna perbedaan tersebut. Dakwah Islamiyah mewajibkan muslim bergerak dan berusaha untuk mewujudkan nilai-nilai Islam, ditengaah-tengah masyarakat. Untuk mencapai tuntutan tersebut diperlukan suatu kegiatan yang dilakukan secara bersama dan terkoordinasi yaitu amal jama'i.

Seperti halnya ormas terbesar Islam Nahdlatul ulama' mempunyai peran di bidang agama, melaksanakan dakwah Islamiyah dan 
meningkatkan rasa persaudaraan yang berpijak pada semangat persatuan dalam perbedaan, Di bidang pendidikan, menyelenggarakan pendidikan yang sesuai dengan nilai-nilai Islam, untuk membentuk muslim yang bertakwa, berbudi luhur, berpengetahuan luas, Di bidang sosial-budaya, mengusahakan kesejahteraan rakyat serta kebudayaan yang sesuai dengan nilai ke-Islaman dan kemanusiaan, di bidang ekonomi, mengusahakan pemerataan kesempatan untuk menikmati hasil pembangunan, dengan mengutamakan berkembangnya ekonomi rakyat,.

\section{Penutup}

Dari pemaparan yang telah diuraikan di atas dapat ditarik benang merah bahwa: Pertama, nilai-nilai keislaman sebenarnya telah tumbuh, jauh sebelum Indonesia merdeka, nilai-nilai tersebut kemudian bersinergi dengan aspek kebudayaan dan aspek sosial dalam masyarakat, sehingga tanpa disadari praktek beragama sesungguhnya telah dijalankan dan melebur kedalam rutinitas sehari-hari yang dijalankan oleh masyarakat, praktek semacam itu dapat dijumpai misalnya dalam transaksi jual beli yang didalamnya terkandung unsur Ijab-qabul, pernikahan yang dalam sisi prinsipnya telah tersentuh oleh prinsip-prinsip keislaman, walaupun tidak menafikan masih melekatnya tradisi kejawen dalam praktek teknisnya.

Kedua, prinsip-prinsip keislaman yang telah membaur dengan kebudayaan yang ada selanjutnya mampu bertransisi ke dalam pranatapranata sosial dalam masyarakat, pranata sosial tersebut lekat dengan sebutan lembaga ataupun institusi. Eksistensi lembaga Islam yang ada lahir karna adanya pergesekan tingkat kebutuhan dengan kondisi masyarakat ketika itu, sehingga keberadaannya lebih berperan sebagai fasilitator untuk memenuhi hajat masyarakat ketika itu, posisi lembaga ini menjadi sangat penting manakala masyarakat dalam keadaan skeptis dalam mencari status hukum atas permasalahan yang dihadapi dan lembaga Islam yang ada mampu menjawab kebutuhan itu. inilah yang mempertegas betapa urgennya eksistensi lembaga Islam ditengah masyarakat. Lembaga Islam yang demikian itu diistilahkan dengan sebutan Infrastruktur.

Ketiga, untuk mempertegas kedudukan lembaga infrastruktur dalam masyarakat sehingga mempunyai kekuatan hukum mengikat untuk warga Negara, maka pemerintah dengan asas kedaulatannya membentuk lembaga Islam yang mempunyai kekuatan hukum mengikat kepada 
warga Negara Indonesia yang Muslim, wujud keberadaan lembaga suprastruktur (Bentukan pemerintah) ini sebagai langkah terciptanya kepastian hukum bagi orang Islam yang akan menyelesaikan urusannya. Baik mengenai status perkawinan, wakaf, zakat dan sebagainya semua telah ditangani oleh pemerintah melalui lembaga suprastruktur tersebut.

Keempat, baik lembaga infrastruktur maupun suprastruktur keduanya mempunyai andil besar dalam memajukan potensi warga Negara terutama yang beragama Islam, keberadaan lembaga tersebut mampu memberikakan kontrol sikap masyarakat yang jauh dari nilai religiuisitas, mendorong masyarakat kearah kemajuan dengan memberikan bekal pengetahuan khususnya dibidang keagamaan dan meningkatkan sumber daya manusia lewat kegiatan sosial keagamaan, disamping itu juga lembaga tersebut memberikan fasilitas kepada masyarakat yang membutuhkan pelayanan di berbagai sektor administrasi Negara.

\section{Daftar Pustaka}

Cik Hasan Bisri. Hukum Islam Dalam tatanan Masyarakat Indonesia, cet. Pertama. Jakarta: Logos, 1998.

Faisal Ismail. Islam Tranformasi Sosial dan Kontinuitas Sejarah. Yogyakarta: Tiara Wacana, 2001.

Fatkhurrahman Djamil. Metode Ijtihad Majlis Tarjih Muhammadiyah. Jakarta: Logos, 1995.

Irwan Prayitno. Fiqhul Dakwah. cet. Pertama. Jakarta: Pustaka Tarbiatuna, 2002.

Moh Ali Aziz. "Hubungan Antar Umat Beragama Dalam Perspektif Ajaran Islam", Dialog Mahasiswa Intern Dan Antar Umat Beragama Se Jawa Timur, 2001.

Miriam Budiardjo. Dasar-Dasar Ilmu politik. Jakarta: PT. Gramedia Pustaka Utama, 2008.

Mohammad Daud Ali. Hukum Islam: Pengantar Ilmu Hukum dan Tata Hukum Islam di Indonesia. cetakan ke-V. Jakarta:PT. Raja Grafindo Persada, 1996.

Munawir Sjadzali. Landasan pemukiran politik hukum Islam dalam rangka menentukan peradilan Agama di Indonesia, dalam Djun Surdjaman (ed), Hukum Islam di Indonesia:Pemikiran dan praktek. Bandung: Remaja Rosdakarya, 1991.

Philippus M Hadjon. Lembaga Tertinggi dan Lembaga -lembaga Tinggi Negara 
sesuai Undang Undang Dasar 1945: Suatu Analisa Hukum dan Kenegaraan. Surabaya: PT Bina Ilmu, 1992.

Satjipto Rahardjo. Ilmu Hukum. Bandung: PT. Citra Aditya Bakti, 2000.

Th. Sumartana, dkk. Pluaralisme,konflik dan Pendidikan Agama di Indonesia. Yokyakarta:Dian Interfiedi 2001.

Tugas Pokok Kementrian Agama, https://kemenag.go.id/artikel/tugasdan-fungsi.

Wahyu Agung Riadi, 2020, Hukum Islam, Blog, http:/ / wahyuagungriyadiblog.blogspot.com/2011/03/lembagahukum-Islam-di-indonesia.html. 